\title{
Attitude, Risk Perception and Public Acceptance Coronavirus Disease 2019 Vaccination in Indonesia
}

\author{
Andi Susilawaty ${ }^{1}$, Fajrin Noviyanto ${ }^{2}$, lis Afrianty $^{3}$ (D) Armia Syahputra ${ }^{4}$, Lia Kurniasari ${ }^{5}$ (D) Lukman Handoko ${ }^{6}$, \\ Respati Wulandari ${ }^{7}$, Cipta Pramana ${ }^{8 *}$ (D) \\ ${ }^{1}$ Department of Public Health, Medical and Health Science Faculty, UIN Alauddin Makassar, South Sulawesi, Indonesia; \\ ${ }^{2}$ Pharmacy Study Program, STIKes Salsabila Serang, Serang, Indonesia; ${ }^{3}$ Department of Nursing, Sembilanbelas November \\ University Kolaka, Kolaka, Indonesia; ${ }^{4}$ Department of Periodontics, Faculty of Dentistry, Universitas Sumatera Utara, Medan, \\ Indonesia; ${ }^{5}$ Program Study of Public Health, Universitas Muhammadiyah Kalimantan Timur, East Kalimantan, Indonesia; \\ ${ }^{6}$ Occupational Safety and Health Study Program, Politeknik Perkapalan Negeri Surabaya, Surabaya, Indonesia; ${ }^{7}$ Public Health \\ Study Program, Dian Nuswantoro University, Semarang, Indonesia; 8Department of Obstetrics and Gynecology, Faculty of \\ Medical, Tarumanagara University, Jakarta, Indonesia
}

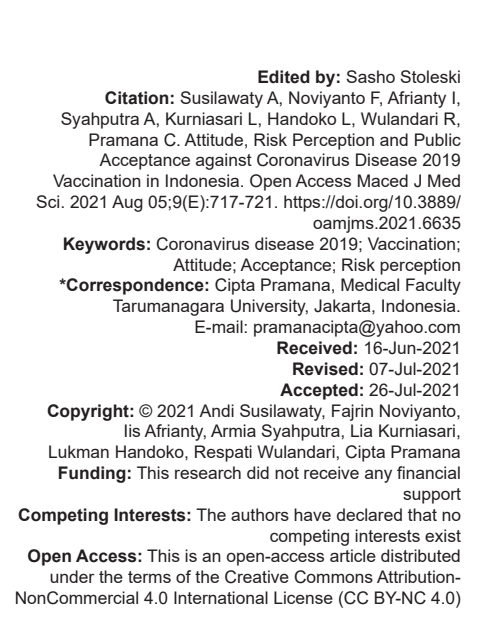

Abstract

BACKGROUND: The presence of a coronavirus disease 2019 (COVID-19) vaccine is very important to produce an immune response that slows down the pandemic.

AIM: This study aims to find out more about the perspective of the Indonesian people which is predicted to affect vaccine acceptance by the public.

METHODS: Quantitative research was conducted using an online survey via a Google form. The survey was conducted from January to February 2021.

RESULTS: There were 225 respondents. The attitude of the community towards the COVID-19 vaccination program, almost all respondents know the free vaccination program (94.4\%) and know the purpose of the program (91.8\%). There were $23 \%$ of respondents who felt that after being vaccinated they would be free from COVID-19 infection and $2.4 \%$ stated that they no longer needed to apply health protocols after being vaccinated. There were $8.2 \%$ who did not agree with the reasons they did not know its effectiveness, were worried about the side effects and were unsure about the safety of the COVID-19 vaccine.

CONCLUSION: In general, self-confidence, comfort, calculation of benefits versus disadvantages, and shared responsibility, influence a person's decision to refuse or accept the vaccine.

\section{Introduction}

Indonesia has passed 1 year of coronavirus disease 2019 (COVID-19) after being declared a global public health crisis by the WHO following the discovery of the first case in March 2020. New hope in February 2021 for Indonesian citizens due to the start of the vaccine program for health workers in Indonesia.

The COVID-19 vaccine has developed rapidly in recent months. The presence of this vaccine is critical to generating an immune response that slows the pandemic. There are now several vaccines that are effective in preventing COVID-19 infection. Indonesia is one of the vaccine users with a total target of $181,554,468$ people, until March only 4,468,951 people were realized for the first vaccine and 1,716,749 people for the second vaccine [1].

The vaccination program for the people of Indonesia with a large area and a population of hundreds of millions of people requires good planning. The government as the organizer must ensure that the program can be implemented effectively so that people throughout Indonesia can immediately receive the vaccine in the shortest possible time. Procurement and implementation of vaccine delivery programs as a measure to overcome the COVID-19 pandemic are regulated through Presidential Regulation of the Republic of Indonesia No. 99 of 2020 concerning Vaccine Procurement and Vaccination Implementation in the Context of Coping with COVID-19 [2]. The Presidential Regulation stipulates that PT. Bio Farma, a stateowned pharmaceutical company, provides vaccines in collaboration with various international institutions.

This Presidential Regulation also stipulates the Ministry of Health to regulate the distribution of vaccines and the national vaccination program. The National Immunization Expert Advisory Committee Indonesian Technical Advisory Group on Immunization (ITAGI) has evaluated the situation related to COVID-19 vaccination 
and provided several recommendations regarding vaccine access for priority groups. The Ministry of Health, supported by ITAGI and development partners, has compiled standard operating procedures and a roadmap for COVID-19 vaccination. These instruments have been distributed to all provinces, including instruments to assess public acceptance of the ongoing COVID-19 vaccination program. The Ministry of Health, with support from UNICEF and WHO, has conducted an online survey in Indonesia to understand the public's views, perceptions, and concerns regarding the COVID-19 vaccination [3].

Public perception of health and disease prevention with vaccines is an important factor in the success of this COVID-19 vaccine program. Research on the COVID-19 vaccine conducted by Callaghan et al. shows that one-third of adults in the USA are not willing to be vaccinated even though the vaccine is available, in contrast to the results of a study conducted by Detoc et al., which stated that $75 \%$ of respondents received the vaccine. Doubts about vaccines will be a major barrier to any COVID-19 vaccination program. There are several things that contribute to vaccine doubt, including demographic characteristics, vaccine knowledge, perceptions of susceptibility to COVID19, COVID-19 risk factors, and politics. The increased perception of risk will be accompanied by an increased desire to vaccinate against COVID-19. Intention for vaccines is related to positive attitudes toward vaccines in the form of benefits and perceptions of vaccines [4], [5], [6], [7], [8].

The results of the initial survey on preparations for the COVID-19 vaccination in Indonesia by the Ministry of Health showed that around $74 \%$ of respondents admitted to more or less know the Government's plan to carry out COVID-19 vaccination nationally. The percentage varies between provinces. Around $61 \%$ of respondents in Aceh answered that they knew the Government's plan related to the distribution of the COVID-19 vaccine; while in several provinces in Sumatra, Sulawesi, and the Nusa Tenggara Islands, $65-70 \%$ of respondents know this information. The number of respondents in the provinces of Java, Maluku, Kalimantan, Papua, and some other provinces who know this information is higher, at around $70 \%$. This survey does not reveal the factors that cause variation [3]. This study aims to find out more about the perspective of the Indonesian people which is predicted to affect vaccine acceptance by the community.

\section{Methods}

\section{Study design}

Quantitative research was conducted using an online survey via a google form. The survey was conducted from January to February 2021 and obtained as many as 225 respondents. Data are collected by sending questionnaire forms to various social media such as Facebook, Wechat, WhatsApp, Instagram, Twitter, Messenger, and/or Websites and official email accounts from several organizations, agents, or other media. Their responses will be automatically stored in the database and will be kept confidential, the time allotted to answer is approximately $5 \mathrm{~min}$. The study has received approval from the ethics committee of KRMT Wongsonegoro Hospital Semarang No.B/0793/070/ II/2021.

\section{Analyses}

Processing and data analysis using a computer statistics program (SPSS16.0). The results of processing and statistical tests obtained are presented in the form of tables and graphs. In this study using univariate analysis, namely, the analysis used on each variable from the results of the study in this analysis resulted in the distribution and frequency of each variable studied, namely the demographic characteristics of respondents consisting of age, gender, marital status, last education, occupation, income, and characteristics of the area of residence. Other variables studied were attitudes, risk perceptions, and public acceptance of the COVID-19 vaccination program.

\section{Results}

\section{Demographic characteristics}

A total of 255 respondents participated in this study. The demographic characteristics of the respondents are presented in Table 1. Of the total respondents, most of them are in the age range of 18-25 years (late teens) as many as 131 people (51.4\%), by gender 179 respondents are female (70.2\%), some respondents have not/unmarried (58\%), 96 people $(37.6 \%)$ have a high school education or equivalent, generally, respondents are students (46.3\%). In terms of income, 139 people $(54.5 \%)$ have an average income of $<2$ million and live in administrative districts/ cities (40\%).

\section{Public attitudes regarding the COVID-19 vaccination program}

When viewed from the attitude of the community regarding the COVID-19 vaccination program, almost all respondents were aware of the free vaccination program (94.4\%) and knew the purpose of the program (91.8\%). $54.1 \%$ of the public obtain information from social media (Facebook, Whatsapp. Twitter, Telegram, 
Table 1: Demographic characteristics of respondents

\begin{tabular}{|c|c|c|}
\hline Demographic characteristics & Frequency & Percentage \\
\hline \multicolumn{3}{|l|}{ Age group } \\
\hline $18-25$ years (late teens) & 131 & 51.4 \\
\hline $26-35$ years old (early adulthood) & 54 & 21.2 \\
\hline 36-45 years (late adulthood) & 23 & 9.0 \\
\hline $46-55$ years old (early elderly) & 40 & 15.7 \\
\hline $56-65$ years (late seniors) & 7 & 2.7 \\
\hline \multicolumn{3}{|l|}{ Gender } \\
\hline Man & 76 & 29.8 \\
\hline Women & 179 & 70.2 \\
\hline \multicolumn{3}{|l|}{ Marital status } \\
\hline Not yet/not married & 148 & 58.0 \\
\hline Married & 103 & 40.4 \\
\hline Widow widower & 3 & 1.2 \\
\hline Choose not to submit & 1 & 0.4 \\
\hline \multicolumn{3}{|l|}{ Last education } \\
\hline High school/equivalent & 96 & 37.6 \\
\hline Diploma & 36 & 14.1 \\
\hline Bachelor-S1 or equivalent & 91 & 35.7 \\
\hline Postgraduate-S2. Profession/equivalent & 28 & 11.0 \\
\hline Doctoral-S3 or equivalent & 4 & 1.6 \\
\hline \multicolumn{3}{|l|}{ Profession } \\
\hline Private employees & 60 & 23.5 \\
\hline Civil Servants (PNS/ASN) & 37 & 14.5 \\
\hline TNI/Polri & 2 & 0.8 \\
\hline Business/Business Owner & 22 & 8.6 \\
\hline Student/Student & 118 & 46.3 \\
\hline Retired & 1 & 0.4 \\
\hline Unemployed/Not working & 15 & 5.9 \\
\hline \multicolumn{3}{|l|}{ Income } \\
\hline$<2$ million & 139 & 54.5 \\
\hline 2-3 million & 25 & 9.8 \\
\hline 3-5 million & 41 & 16.1 \\
\hline More than 5 million & 50 & 19.6 \\
\hline \multicolumn{3}{|l|}{ Characteristics of the area of residence } \\
\hline Rural & 66 & 25.9 \\
\hline Administrative District/City & 102 & 40.0 \\
\hline Big city & 87 & 34.1 \\
\hline
\end{tabular}

Instagram, etc.) and another $32.5 \%$ obtain information from electronic media (TV and radio). Nevertheless, there are still $5.1 \%$ of the public who have not been exposed to free vaccination information and $8.2 \%$ do not know the purpose of the COVID-19 vaccination program.

Of the 255 respondents, 179 people $(70.2 \%)$ have not received information about the COVID-19 vaccination program directly from official government sources (local government, health officials/officers). Almost all people (91.8\%) agree with the vaccine program provided by the government for the general public, but there are still $8.2 \%$ who disagree because that they do not know its effectiveness, are worried about side effects, and are unsure of the safety of the COVID-19 vaccine. Respondents' attitudes regarding the COVID-19 vaccination program are presented in Table 2.

\section{Community risk perception after receiving COVID-19 vaccination}

Two questions were used to assess the community's perceived risk of COVID-19 infection after vaccination. $23 \%$ of respondents perceived that after being vaccinated, they would be free from COVID-19 infection and $2.4 \%$ stated that they no longer needed to apply the (3M) health protocol after being vaccinated. The distribution of respondents' answers is shown in Table 3.
Table 2: Distribution of respondents' attitudes regarding the COVID-19 vaccination program

\begin{tabular}{|c|c|c|}
\hline Attitude & Frequency & Percentage \\
\hline \multicolumn{3}{|l|}{$\begin{array}{l}\text { Knowing the COVID-19 vaccination program that will be } \\
\text { provided by the government for free for the general public }\end{array}$} \\
\hline Do not know & 13 & 5.1 \\
\hline Tofu & 242 & 94.9 \\
\hline \multicolumn{3}{|c|}{$\begin{array}{l}\text { Knowing the purpose of the COVID-19 vaccination program for } \\
\text { all Indonesian people }\end{array}$} \\
\hline Do not know & 21 & 8.2 \\
\hline Tofu & 234 & 91.8 \\
\hline \multicolumn{3}{|l|}{ Sources of information about vaccines } \\
\hline Electronic Media (TV and Radio) & 83 & 32.5 \\
\hline Mass Media (Newspaper, Magazine, Bulletin) & 6 & 2.4 \\
\hline Friends, relatives, colleagues & 10 & 3.9 \\
\hline $\begin{array}{l}\text { Social Media (Facebook, Whatsapp. Twitter, Telegram, } \\
\text { Instagram, etc) }\end{array}$ & 138 & 54.1 \\
\hline World Health Organization Website & 4 & 1.6 \\
\hline Indonesian government official website & 14 & 5.5 \\
\hline \multicolumn{3}{|c|}{$\begin{array}{l}\text { Receive information about the COVID-19 vaccination program } \\
\text { directly from official government sources (local government, } \\
\text { health officials/officers) }\end{array}$} \\
\hline Not yet & 179 & 70.2 \\
\hline Already & 76 & 29.8 \\
\hline \multicolumn{3}{|l|}{$\begin{array}{l}\text { Agree with the vaccine program provided by the government } \\
\text { for the general public }\end{array}$} \\
\hline Disagree & 21 & 8.2 \\
\hline Agree & 234 & 91.8 \\
\hline \multicolumn{3}{|l|}{ Reasons for disagreeing with the COVID-19 vaccine program } \\
\hline Don't know how effective it is & 4 & 1.6 \\
\hline Worried about the side effects & 4 & 1.6 \\
\hline Not sure the safety & 13 & 5.1 \\
\hline
\end{tabular}

Source: Primary Data, 2020

Table 3: Community risk perception of COVID-19 infection after vaccination

\begin{tabular}{lll}
\hline Risk perception & Frequency & Percentage \\
\hline After being vaccinated, you will be free from COVID-19 & 61 & 23.9 \\
Yes & 194 & 76.1 \\
Not & & \\
After being vaccinated, it is still necessary to apply the (3 M) & & \\
health protocol & 249 & 97.6 \\
Yes & 6 & 2.4 \\
Not & &
\end{tabular}

\section{Public acceptance of COVID-19 vaccination}

A total of nine statements were used to see public acceptance of the COVID-19 vaccination using the answer choices from very inappropriate (Score 1) to very appropriate with the conditions experienced by the respondent (Score 5) measured by a differential semantic scale arranged in a continuum line. On average, people are happy because they will get free vaccinations, but they are still worried because there is no clear information on the choice of the type of COVID-19 vaccine that will be given. In principle, the average community feels ready to be vaccinated against COVID-19 as long as the choice of the type of COVID-19 vaccine that will be given to the community has clear benefits and effectiveness, and it has been proven that the benefits are greater than the side effects that will be caused. The average community answers are presented in Table 4.

\section{Discussion}

Vaccination is one of the important programs carried out by various countries to control the COVID-19 
Table 4: Public acceptance of the COVID-19 vaccine

\begin{tabular}{lll}
\hline Statement & Mean & SD \\
\hline $\begin{array}{l}\text { 1. People are happy because they will get the COVID-19 vaccination } \\
\text { for free }\end{array}$ & 3.96 & 1.062 \\
2. People are worried because there is no clear information on the & 3.46 & 1,248 \\
choice of the type of COVID-19 vaccine that will be given to the & & \\
$\quad \begin{array}{l}\text { general public for free } \\
\text { 3. The public is willing to be vaccinated if the choice of the type of } \\
\text { COVID-19 vaccine to be given to the community has clear benefits } \\
\text { and effectiveness }\end{array}$ & 4.27 & .943 \\
$\begin{array}{l}\text { 4. The public feels that it is better to be vaccinated if the choice of the } \\
\text { COVID-19 vaccine to be given to the community has proven to be of }\end{array}$ & 4.37 & .938 \\
greater benefit than the side effects that will be caused & & \\
$\begin{array}{l}\text { 5. People feel calm and safe if they have participated in the COVID-19 } \\
\text { vaccination program }\end{array}$ & 3.73 & 1.153 \\
6. Following the COVID-19 vaccine program is one of the efforts to avoid & 3.91 & 1,110 \\
the COVID-19 virus & & 1,289 \\
7. The public will accept, whatever the choice of the type of COVID-19 & 3.27 & vaccine that will be given by the government \\
$\begin{array}{l}\text { 8. The community will invite family members to get vaccinated according } \\
\text { to the government program }\end{array}$ & 3.85 & 1.089 \\
9. In principle, people feel ready to be vaccinated against COVID-19 & 3.92 & 1.169 \\
\hline Source: Primary Data, 2020. & &
\end{tabular}

pandemic. Several important variables in the success of the COVID-19 vaccination coverage examined in this survey are attitudes, perceptions of risk, and public acceptance of vaccinations that were started last week. The more people who are willing to be vaccinated, the bigger the coverage.

The high coverage of vaccination is largely determined by the level of public knowledge. When viewed from the public's knowledge regarding the COVID-19 vaccination program, almost all respondents $(94.4 \%)$ already knew about the implementation $(94.4 \%)$ and objectives $(91.8 \%)$ of the free vaccination program that will be provided by the government. Information on this program was obtained from various social media platforms, including Facebook, Whatsapp. Twitter, Telegram, Instagram, etc. Nevertheless, there are still $5.1 \%$ of the public who have not been exposed to free vaccination information and $8.2 \%$ do not know the purpose of the COVID-19 vaccination program. In this case, the role of social media is very large to encourage people to be willing to be vaccinated.

From the results of this study, it can be seen that if in the next 15 months, the Indonesian government targets more than 180 million people (equivalent to $70 \%$ of the total population) to be vaccinated to create community immunity in the face of the vicious coronavirus so that this vaccination program is successful, the campaign design of this free mass vaccination program should be more intensely aimed at people who have not been exposed to free vaccination information and do not yet know the purpose of the COVID-19 vaccination program.

In the attitude aspect, this study shows that almost all people (91.8\%) agree with the vaccine program provided by the government for the general public but there are still $8.2 \%$ who disagree because they do not know its effectiveness, are worried about side effects and are unsure of the safety of the COVID-19 vaccine. The same survey has been carried out by the Ministry of Health showed relatively similar results that only $64.8 \%$ were willing to be vaccinated.
Others, $7.6 \%$ strongly rejected the COVID vaccination and $27.6 \%$ said they did not know [3].

Some of the reasons for disapproval were not knowing its effectiveness, worrying about side effects, and not knowing the safety level of the vaccine to be given. Researchers and the government in this case as vaccination implementers need to understand the levels of public doubt about vaccines including their reasons so that they can develop the right campaign to change the attitudes and thoughts of the targeted people [9].

Public trust in the benefits of vaccines is a series that has gradations. Some people accept all vaccination programs and ideally believe in their efficacy until some reject it altogether even though the vaccine is available. A person's attitude and decision-making to participate in a vaccination program is a complex issue because it is intertwined with demand for and access to health services [10]. In addition, this phenomenon is very sensitive to context, varies between times, places, and types of vaccines. A person may refuse to be vaccinated against polio for their child, for example, but the same person is willing to accept being vaccinated against COVID-19 [9]. A person's decision to refuse vaccination is not entirely based on unreasonable or even conspiratorial reasons. The same thing was obtained from the Ministry of Health survey, in the group that refused the vaccine at all $(7.6 \%)$, the majority of respondents $(52 \%)$ planned to refuse the COVID-19 vaccination because they were not sure about its safety and effectiveness [3].

Since the government announced the COVID19 vaccination in Indonesia, the public has been faced with various dilemmas in implementing this policy. This dilemma also arises due to the perception of the risks that exist in society regarding the COVID-19 vaccine [11]. Two questions were used to assess the community's risk perception of COVID-19 infection after vaccination. $23 \%$ of respondents felt that after being vaccinated they would be free from COVID-19 infection and $2.4 \%$ stated that they no longer needed to apply health protocols (wearing a face masks, physical/social distancing, and washing hands with soap) after being vaccinated.

Vaccination decisions will depend on the calculation of benefits resulting from a person's evaluation of the various information he receives about the vaccination program. In addition, the vaccination program must be seen as a collective responsibility because a new vaccination program can only see the benefits if there are enough people who are successfully vaccinated to form community immunity. The weakness of the COVID-19 vaccination program is that there is no marker for the formation of community immunity which is the goal of community vaccination [12]. It can be seen from the answers of the respondents in this study that the average community is happy because they will get free vaccinations, but they are still worried because the information on the choice of the type of COVID-19 vaccine 
that will be given is not clear. In principle, the community feels ready to be vaccinated against COVID-19 as long as the choice of the type of COVID-19 vaccine that will be given to the community has clear benefits and effectiveness, and it has been proven that the benefits are greater than the side effects that will be caused.

The same research was conducted in Uganda shows that public acceptance of the COVID-19 vaccine is only $53.6 \%$. In general, confidence, comfort, the calculation of benefits versus harm, and shared responsibility, influence a person's decision to refuse or accept a vaccine [3], [12], [13]. Confidence refers to a person's belief in the efficacy and safety of a vaccine; the health system that provides it, including the competence of health facilities and personnel; and motivation of policymakers for vaccination programs. Inattention to the risk of transmitting the COVID-19 virus can be caused by the low individual perception of the vaccination benefits. With this perception, vaccination is not considered an important preventive measure. Convenience includes affordability, vaccine availability, access to health services, health knowledge, and literacy, and more. Convenience is the most prominent determinant in determining vaccination decisions.

\section{Conclusion}

This study concludes that almost all people $(91.8 \%)$ agree with the COVID-19 vaccination program. There are $8.2 \%$ who disagree because they do not know its effectiveness, are worried about side effects and are unsure of the safety of the COVID-19 vaccine.

\section{Acknowledgment}

Thank you to the Health Research Ethics Committee of the KRMT Wongsonegoro General Hospital, Semarang City, who has given research permission and the respondents who took part in the research.

\section{Ethical Consideration}

The authors have entirely observed ethical issues (Including plagiarism, informed consent, misconduct, data fabrication and/or falsification, double publication and/or submission, redundancy, etc.).

\section{References}

1. Nadia S. Kebijakan Pelaksanaan Vaksinasi COVID-19 Direktorat Jenderal Pencegah dan Pengendali Penyakit Kementeri Kesehatan [Internet]. 2020;1-46. Available from: https://persi.or.id/wp-content/uploads/2021/01/paparan adinkes_rakernassus.pdf.

2. Ministry of Health RI Director-General of P2P. Decree of the Director-General of Disease Prevention and Control Number Hk.02.02/4/1/2021 concerning Technical Guidelines for Vaccination Implementation in the Context of Combating the 2019 Corona Virus Disease (COVID-19) Pandemic. Indonesian Ministry of Health; 2020. p. 114. https://doi. org/10.24321/2455.7048.202013

3. Ministry of Health of the Republic of Indonesia, ITAGI, WHO UNICEF. Survey of COVID-19 Vaccine Acceptance in Indonesia, COVID-19 Handling Task Force. Indonesia: Ministry of Health of the Republic of Indonesia; 2020.

4. Callaghan T, Moghtaderi A, Lueck JA, Hotez P, Strych U, Dor $A$, et al. Correlates and disparities of intention to vaccinate against COVID-19. Soc Sci Med. 2021;272:113638. https://doi. org/10.1016/j.socscimed.2020.113638

PMid:33414032

5. Detoc M, Bruel S, Frappe P, Tardy B, Botelho-Nevers E, Gagneux-Brunon A. Intention to participate in a COVID-19 vaccine clinical trial and to get vaccinated against COVID-19 in France during the pandemic. Vaccines. 2020;38(45):7002-6. https://doi.org/10.1101/2020.04.23.20076513 PMid:32988688

6. Mendez-Ruiz MD, Alonso-Castillo MT, Alonso-Castillo MM, Uribe-Alvarado JI, Armendáriz-García NA. Relationship between risk perception and alcohol consumption in adolescents. SMAD Rev Eletrôn Saúde Ment Álcoole Drogas. 2015;11(3):161-7. https://doi.org/10.11606/issn.1806-6976.v11i3p161-167

7. Caserotti M, Girardi P, Rubaltelli E, Tasso A, Lotto L, Gavaruzzi T. Associations of COVID-19 risk perception with vaccine hesitancy over time for Italian residents. Soc Sci Med. 2021;272:113688. https://doi.org/10.1016/j.socscimed.2021.113688 PMid:33485215

8. Sturm L, Kasting ML, Head KJ, Hartsock JA, Zimet GD. Influenza vaccination in the time of COVID-19: A national US survey of adults. Vaccine. 2021;39(14):1921-8. https://doi.org/10.1016/j. vaccine.2021.03.003

PMid:33715898

9. Paul E, Steptoe A, Fancourt D. Attitudes towards vaccines and intention to vaccinate against COVID-19: Implications for public health communications. Lancet Reg Health Eur. 2021;1:100012. https://doi.org/10.1016/j.lanepe.2020.100012 PMid:33954296

10. Ophinni $Y$, Hasibuan AS, Widhani A, Maria S, Koesnoe $S$, Yunihastuti $\mathrm{E}$, et al. COVID-19 vaccines: Current status and implications for use in Indonesia. Acta Med Indonesia. 2020;52(4):388-412. PMid:33377885

11. World Health Organization. Evaluation of COVID-19 Vaccine Effectiveness. Geneva: World Health Organization; 2021. p. 70.

12. Akbar I. Covid-19 vaccination and state policy: Political economy perspective. J Acad Praja. 2021;4(1):244-54.

13. Echoru I, Ajambo PD, Bukenya EM. Acceptance and Risk Perception of COVID-19 Vaccine in Uganda: A Cross-Sectional Study in Western Uganda. Res Sq. 2020;2020:1-11. https://doi. org/10.21203/rs.3.rs-78780/v1 